Yaremko L. A., Doctor of Economic Sciences, Professor

Lviv University of Trade and Economics

Lviv, Ukraine

Yaremko S. A., PhD student

Institute of Regional Research named after M. I. Dolishniy

Lviv, Ukraine

DOI: https://doi.org/10.30525/978-9934-26-036-0-22

\title{
FINANCIAL SOURCES \\ OF THE REGIONAL INNOVATIVE ACTIVITY \\ IN THE FRAMEWORK OF SMART SPECIALIZATION
}

Supporting innovative activity in the implementation of the smart specialization strategy is one of the most important steps in the further process of its effective implementation. A definition of ways to financially support this strategy is considered to be an essential instrument for the development of modern innovation policy in Ukraine and the world altogether. The country's innovative activity is specifically linked to regional development. The necessary financial support of newly established organizations is possible to be obtained on the regional level. It is worth pointing out that innovations are a major aspect of building an effective regional innovation policy. Smart specialization strategy is designed to ensure the development and implementation of this policy. Establishment of innovations is impossible without the primary occurrence of innovative enterprises. Innovative enterprises producing innovative products (goods) should constitute the drivers of economic development in the region.

The attraction of financial resources for the above-mentioned enterprises is one of the main tasks of its formation. Nevertheless, it should be noted that not all traditional types of financing apply to such enterprises. Funding largely depends on the development stage of the innovative product: R\&D of the product; product concept creation; product development; market separation and product testing on it; initial production; product delivery; costs of marketing operations concerning the product, etc. [1, p. 2]. 
It is possible to distinguish certain stages of financing regarding the use of financial resources by the enterprise, taking into account such stages of product development (Table 1).

Table 1

Stages of use of financial resources by the enterprise

\begin{tabular}{|c|c|c|}
\hline $\begin{array}{l}\text { № } \\
\text { ПI/II }\end{array}$ & Title of the stage & Characteristics of the stage \\
\hline 1. & $\begin{array}{l}\text { The primary stage } \\
\text { (seed stage) }\end{array}$ & $\begin{array}{l}\text { - funding of the initial stage of the study; } \\
\text { - commercialization of the idea; } \\
\text { - formation of a business concept; } \\
\text { - determination of technical and market } \\
\text { potential. }\end{array}$ \\
\hline 2. & Start-up stage & $\begin{array}{l}\text { - development of a product prototype; } \\
\text { - initial market research and its activities; } \\
\text { - formation of a business organization. }\end{array}$ \\
\hline 3. & Early-growth stage & $\begin{array}{l}\text { - formation of small commercialization; } \\
\text { - foundation for the ability of a business to } \\
\text { further development; }\end{array}$ \\
\hline 4. & The expansion stage & $\begin{array}{l}\text { - business growth and formation of its } \\
\text { influence on the market. }\end{array}$ \\
\hline
\end{tabular}

Source: $[1, p .2 ; 2, p .9]$

There are high risks of unprofitability and lack of funds at the beginning of its establishment (in the initial stages of founding innovative enterprises). That is why such enterprises should attract funds that do not require guaranteed payments [1, p. 1]. The financial resources that are regarded as efficient at the primary stage of the development of an innovative enterprise include the own funds of the founders, the funds of family, friends and other related investors [3, p. 1].

In addition to the aforementioned sources of funding, innovative enterprises can raise funds through [1]:

1. Grants for feasibility studies provided by public authorities. They are considered to be an effective source of funding for innovation entities at an early stage.

2. Cooperation with state research institutions to attract appropriate funding for innovation development. 
3. Business support services - attracting financial backing through understanding the needs of business and awareness of business plans of individual investors and information and consulting support for enterprise innovation.

4. Microloans (small loans of less than 25,000 euros to support business activities) which are provided mainly by specialized microfinance institutions (loan funds, non-governmental organizations (NGOs), cooperative banks, financial cooperatives and credit unions), that also have methods of assessing the borrower's solvency [1, p. 18].

5. Business angels - make investments in the share capital of enterprises with high entrepreneurial potential (from 25 thousand euros to 250 thousand euros, as well as from 1 million euros to 2 million euros) [1, p. 21]. They can provide information support services, help with establishing a network of contacts in business circles, as well as share their own experience [5].

6. Corporate venture capital - according to the investment of non-financial corporations in private business [4, p. 72].

Such donors often encourage business development by providing expertise and building the necessary network of connections to reduce investment risk.

There are several ways to attract aforesaid business to finance in the field of innovative enterprises: tax benefits for investment in private innovative enterprises; public-private partnership; formation of administrative structures to create new ideas [1, p. 26].

The domestic innovation market demonstrates insufficient growth rates. Therefore, the state requires to facilitate the intensification of innovation during the formation and implementation of innovation policy. The contemporary innovation system requires reforms and innovations in the areas of organizational structure, management and activity along with fostering of R\&D. The revitalization of innovation activity should contribute to the successful exposure to world markets. Solving the problem of financing an innovative $R \& D$ should enhance the rapid economic development of the country. 


\section{References:}

1. Policy Options and Instruments for Financing Innovation: A Practical Guide to Early-Stage Financing, UNITED NATIONS New York and Geneva, 2009.

2. Badri H., Panchenko Ye., Rudukha N. (2018) Hlobalni determinanty i modeli finansuvannia innovatsii [Global determinants and models of innovation financing]. Mizhnarodna ekonomichna polityka, no. 1, pp. 7-31. Available at: http://nbuv.gov.ua/ UJRN/Mep_2018_1_3.

3. Piliavoz T. (2019) Analiz dzherel finansuvannia innovatsiinoi diialnosti promyslovykh pidpryiemstv [Analysis of sources of financing of innovative activity of industrial enterprises]. Available at: https://conferences.vntu.edu.ua/index.php/allfm/all-fm-2019/paper/view/7774.

4. Dominique Foray (2013). The economic fundamentals of smart specialisation. EKONOMIAZ. Revista vasca de Economía, Gobierno Vasco / Eusko Jaurlaritza / Basque Government, vol. 83(02), pp. 55-82.

5. Danylyshyn B. (2017) Biznes-anhely abo aziatskyi dosvid. Yak pidtrymaty innovatsii [Business angels or asian experience. How to support innovation]. Available at: https://nv.ua/ukr/opinion/biznes-angeli-abo-aziatskij-dosvid-jak-pidtrimati-innovatsiji-2088721.html. 